\title{
Fabrication $\mathrm{Fe} / \mathrm{Fe}_{3} \mathrm{O}_{4} / \mathrm{Graphene}$ Nanocomposite Electrode Material for Rechargeable Ni/Fe Batteries in Hybrid Electric Vehicles
}

\author{
Harish Kumar ${ }^{1, *}$, A. K. Shukla ${ }^{2}$ \\ ${ }^{1}$ Department of Chemistry, Chaudhary Devi Lal University, Sisra - 125055 (Haryana), India \\ ${ }^{2}$ Solid State and Structural Chemistry Unit (SSCU), Indian Institute Of Science, \\ Bangalore - 560 012, India \\ *E-mail address: harimoudgil1@rediffmail.com
}

\begin{abstract}
$\mathrm{Fe} / \mathrm{Fe}_{3} \mathrm{O}_{4} / \mathrm{Graphene}$ composite electrode material was synthesized by a thermal reduction method and then used as anode material along with Nickel cathode in rechargeable Ni/Fe alkaline batteries in hybrid electric vehicles. Reduced graphene $/ \mathrm{Fe} / \mathrm{Fe}_{3} \mathrm{O}_{4}$ composite electrode material was prepared using a facile three step synthesis involving synthesis of iron oxalate and subsequent reduction of exfoliated graphene oxide and iron oxalate by thermal decomposition method. The synthesis approach presents a promising route for a large-scale production of reduced graphene $/ \mathrm{Fe} / \mathrm{Fe}_{3} \mathrm{O}_{4}$ composite as electrode material for $\mathrm{Ni} / \mathrm{Fe}$ rechargeable batteries. The particle size and structure of the samples were characterized by SEM and XRD.
\end{abstract}

Keywords: Graphene; Nanocomposite; rechargeable batteries; $\mathrm{Fe}_{3} \mathrm{O}_{4}$

\section{INTRODUCTION}

As stock of nonrenewable fossil fuel is limited and there is constant demand in shifting towards use of renewable source of energy. Large scale batteries can be used in propulsion of electrical powered vehicles. Safe, low cost, and high energy density are the basic requirements of it. Among the few large scale batteries used in electric vehicle propulsion, of particular interest are lithium ion batteries, in which $\mathrm{LiFePO}_{4}$ is used as the cathode material, $\mathrm{Ni}-\mathrm{Cd}$, metal hydride and $\mathrm{Ni} / \mathrm{Fe}$ batteries. Lithium ion batteries are limited in safety owing to the flammable organic electrolyte contained inside. In contrast, alkaline rechargeable batteries satisfy safety concerns owing to their use of an aqueous electrolyte. The Ni-Fe rechargeable alkaline battery, in which iron is used as the anode and $\mathrm{Ni}(\mathrm{OH})_{2}$ as the cathode material, was developed around 1900, and has a cycle life of 3000 cycles and a calendar life of about 20 years [1]. Nickel-iron batteries are highly promising for large scale battery applications owing to their high theoretical capacity [2], inexpensiveness, and absence of toxic materials [3].

Although the theoretical capacity of iron is $962 \mathrm{mAhg}^{-1}$, but in actual lab test conditions, the iron electrode performed as low as $1 / 3$ of the theoretical value [4-7], owing to the formation of a passive film $[8,18]$. While attempting to enhance the capacity and power 
density of iron active materials, researchers has [9] used the nanosized iron particle, in which the nanosized iron particle discharge capacity is about $700 \mathrm{mAhg}^{-1}(\mathrm{Fe})$ during the first cycle, a capacity that was significantly higher than in other studies. However, the capacity of the active material decreases quickly to less than $300 \mathrm{mAhg}^{-1}$ during the second or third cycle. Although, other investigators made nanosized iron active materials, the reversibility was not improved [10-14]. This work describes a novel composite structure, $\mathrm{Fe} / \mathrm{Fe}_{3} \mathrm{O}_{4} / \mathrm{Graphene}$ composite as negative electrode material and Ni hydroxide as a positive electrode for a rechargeable $\mathrm{Ni} / \mathrm{Fe}$ alkaline batteries with high capacity, large cycle life, high power and energy density.

\section{EXPERIMENTAL}

\section{1. Preparation of active material i.e. Iron oxalate as precursor}

For the synthesis of iron oxalate. $36.2 \mathrm{~g}$ of oxalic acid $\left(\mathrm{C}_{2} \mathrm{H}_{2} \mathrm{O}_{4} \cdot 2 \mathrm{H}_{2} \mathrm{O}\right)$ of AR grade (S. D. Fine-Chem. limited, Mumbai) was dissolved in double distilled water. Nitrogen gas was passed continuously and solution was heated at $80^{\circ} \mathrm{C}$ on hot plate. In another beaker, $73.86 \mathrm{~g}$ of $\mathrm{FeSO}_{4} \cdot 7 \mathrm{H}_{2} \mathrm{O}$ ExcelaR grade (Fisher Scientific Pvt. Ltd., Mumbai) was dissolved in double distilled water. Resulting solution was heated to $80^{\circ} \mathrm{C}$ on hot plate with continuous supply of nitrogen gas up to 15 minutes to remove traces of any dissolved gases.

Oxalic acid solution was slowly added in to ferrous sulphate solution with continuous stirring with magnetic stirrer maintained at a constant temperature of $70.0{ }^{\circ} \mathrm{C}$. The mixture was heated with continuous stirring up to 2 hours. Initially, ferrous sulphate solution was brown in colour. On adding oxalic acid, solution becomes greenish in colour. On ageing solution becomes yellowish in colour. Then we filtered it on Whattmann filter paper fitted with suction pump and washed the precipitate (ferrous oxalate) with deionized water several times. Resulting precipitate was dried in oven maintained at $80.0^{\circ} \mathrm{C}$ for a period of 4 hours. Then we weighed it and stored it.

\section{2. Preparation of $\mathrm{Fe} / \mathrm{Fe}_{3} \mathrm{O}_{4} / \mathrm{Graphene}$ composite for the Negative Electrode}

$30 \mathrm{mg}$ of exfoliated graphene oxide was added in $50 \mathrm{ml}$ of deionized water in $250 \mathrm{ml}$ capacity glass borosil beaker. Then it was kept for ultrasonication for two hours to completely disperse graphene oxide. Then, we added $6.0 \mathrm{~g}$ of iron oxalate into it and again ultrasonicate it for one hour. Then the solution was heated at a temperature of $65-70{ }^{\circ} \mathrm{C}$ with continuous stirring till the formation of gel like semisolid paste. Then we put it in an oven to dry for 4 hours maintained at a constant temperature of $80^{\circ} \mathrm{C}$.

Amount of iron oxalate graphene oxide obtained was $5.9 \mathrm{~g}$. Then it was thermally decomposed with the help of tubular furnace fitted with vacuum pump maintained at a pressure of 0.05 mbar initially at $200{ }^{\circ} \mathrm{C}$ for 45 minutes and then at $400{ }^{\circ} \mathrm{C}$ again for 45 minutes and then at $600{ }^{\circ} \mathrm{C}$ again for 45 minutes. Then it was kept in it for slowly cooling. Then it was cooled under liquid nitrogen and then stored in vacuum desiccator. The final product is $\mathrm{Fe} / \mathrm{Fe}_{3} \mathrm{O}_{4} / \mathrm{Graphene}$ composite electrode material.

\subsection{Preparation of Iron electrode and cell assembly}

For the preparation of negative electrode, $1.0 \% \mathrm{KOH}$ and $0.0021 \mathrm{~m}$ of $\mathrm{NiSO}_{4} \cdot 7 \mathrm{H}_{2} \mathrm{O}$ was taken in $50 \mathrm{ml}$ glass beaker. Then, $1.0000 \mathrm{~g}$ of $\mathrm{Fe} / \mathrm{Fe}_{3} \mathrm{O}_{4} / \mathrm{Graphene}$ composite was added into it along with $12.4 \mathrm{mg}$ of $\mathrm{Bi}_{2} \mathrm{~S}_{3}$. Then we weighed $0.1346 \mathrm{~g}$ of PTFE in another $50 \mathrm{ml}$ 
beaker and added few drops of water into it to dilute it. Then we mix the two to form paste like gel. Then this paste was applied uniformly on both sides of nickel coated iron mesh and put under a load of 65.5 kilo newton for 5.0 minutes. Then the electrode was placed between glass watch slides and put in tubular glass frame through which continuous supply of $\mathrm{N}_{2}$ gas was maintained at a rate of one bubble per two seconds. After 15 minutes, tubular glass frame having working electrode was placed in muffle furnace maintained at $350{ }^{\circ} \mathrm{C}$ for minutes with continuous supply of nitrogen gas.

For making the cell, we assembled counter electrode i.e. $\mathrm{Ni}(\mathrm{OH})_{2}$ supported over stainless steel wire gauze available commercially acting as positive electrode, working test electrode of $\mathrm{Fe} / \mathrm{Fe}_{3} \mathrm{O}_{4} / \mathrm{Graphene}$ acting as negative electrode and a reference electrode i.e. $\mathrm{Hg} / \mathrm{Hg}_{2} \mathrm{Cl}_{2}$ fitted with luggin capillary in the centre of PVC plastic container beaker of approx. $270 \mathrm{ml}$ capacity. Electrolyte used was $6.0 \mathrm{~m} \mathrm{KOH}$ and $1.0 \mathrm{wt}$. \% of LiOH.

\section{RESULT AND DISCUSSION}

\section{1. Electrochemical characterization of Working Electrode}

For the electrochemical characterization of working electrode, we assembled it on multichannel electrochemical workstation (Autolab) for charging-discharge cycle rate and electrochemical impedance study. Figure 1 shows XRD pattern of $\mathrm{Fe} / \mathrm{Fe}_{3} \mathrm{O}_{4} /$ Graphene (35 $\mathrm{mg}$ ) negative electrode material. The peak at an angle of $30.218^{\circ}(220), 35.612^{\circ}$ (311), $43.278^{\circ}$ (400), $53.569^{\circ}$ (422), 57.118 ${ }^{\circ}$ (511), $62.655^{\circ}$ (440) correspond to $\mathrm{Fe}_{3} \mathrm{O}_{4}$. Two peak corresponding to $44.768^{\circ}(110)$ and $65.139^{\circ}$ (200) confirms the presence of metallic Fe. A peak $18.364^{\circ}$ corresponds to the graphene.

Figure 2 shows XRD pattern of $\mathrm{Fe} / \mathrm{Fe}_{3} \mathrm{O}_{4}$ Graphene $(45 \mathrm{mg}$ ) negative electrode material. The peak at an angle of $30.218^{\circ}(220), 35.612^{\circ}(311), 43.278^{\circ}(400), 53.569^{\circ}(422)$, $57.118^{\circ}(511), 62.655^{\circ}$ (440) correspond to $\mathrm{Fe}_{3} \mathrm{O}_{4}$. Two peak corresponding to $44.768^{\circ}$ (110) and $65.139^{\circ}(200)$ confirms the presence of metallic Fe. A peak $18.364^{\circ}$ corresponds to the graphene.

Figure 3 shows capacity evolution during the first 25 cycles of charge-discharge of Fe/ $\mathrm{Fe}_{3} \mathrm{O}_{4}$ /Graphene $(30 \mathrm{mg})$ negative electrode. After some stabilization cycles, which are necessary for the distribution of the sulphate ions in the Fe electrode surface, the electrode shows a marked increase in capacity from 191.01 to $277 \mathrm{mAh} / \mathrm{g}$. The charging current was $62.5 \mathrm{~mA}$ for 8 hours and discharging current was $50 \mathrm{~mA} / \mathrm{g}$. The nominal (operating or discharge) voltage of $\mathrm{Ni} / \mathrm{Fe}$ cells could vary from about $1.23 \mathrm{~V}$ at the $\mathrm{C} / 8$ rate to $0.85 \mathrm{~V}$ at the $\mathrm{C}$ rate.

The charge-discharge reactions of the $\mathrm{Ni} / \mathrm{Fe}$ battery are

$$
\begin{aligned}
& 2 \mathrm{NiOOH}+\mathrm{Fe}+2 \mathrm{H}_{2} \mathrm{O} \stackrel{\text { Discharge }}{\longrightarrow} 2 \mathrm{Ni}(\mathrm{OH})_{2}+\mathrm{Fe}(\mathrm{OH})_{2} \\
& 2 \mathrm{Ni}(\mathrm{OH})_{2}+\mathrm{Fe}(\mathrm{OH})_{2} \stackrel{\text { Charge }}{\longrightarrow} 2 \mathrm{NiOOH}+\mathrm{Fe}+2 \mathrm{H}_{2} \mathrm{O}
\end{aligned}
$$




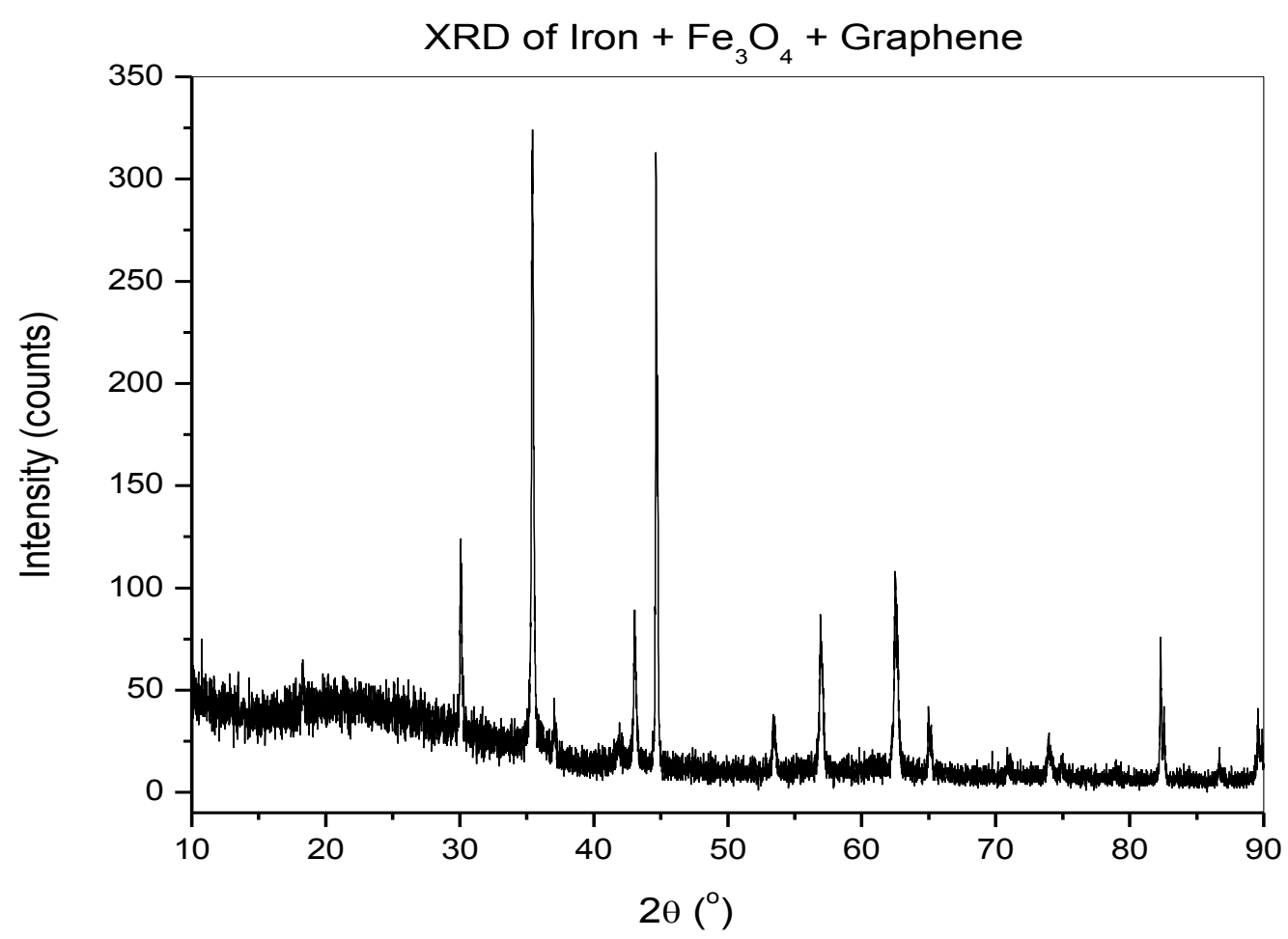

Figure 1. XRD pattern of $\mathrm{Fe} / \mathrm{Fe}_{3} \mathrm{O}_{4}$ Graphene $(30 \mathrm{mg}$ ) negative electrode material.

Figure 4 shows capacity evolution during the first 25 cycles of charge/discharge of Fe/ $\mathrm{Fe}_{3} \mathrm{O}_{4} /$ Graphene $(45 \mathrm{mg})$ negative electrode. The results are almost similar to previous electrode. Figure 5 shows impedance study of $\mathrm{Fe} / \mathrm{Fe}_{3} \mathrm{O}_{4} /$ Graphene $(30 \mathrm{mg}$ ) electrode (Nyquist plot). Figure 6 shows impedance study of $\mathrm{Fe} / \mathrm{Fe}_{3} \mathrm{O}_{4} / \mathrm{Graphene}(45 \mathrm{mg}$ ) electrode (Nyquist plot). Electrochemical impedance spectroscopy (EIS) experiments were performed at constant Potential (AC amplitude/RMS voltage), using a $5.0 \mathrm{mV}$ peak to peak ac potential perturbation in discharge condition at $\mathrm{OCP}$ value of $-0.93 \mathrm{~V}$ versus $\mathrm{Hg} / \mathrm{HgO}$ in frequency range $100 \mathrm{kHz}$ to $5 \mathrm{mHz}$. At each selected potential, the EIS measurement was performed only when a steady state dc current had become established. Impedance spectra, recorded at constant potential for a Fe/ $\mathrm{Fe}_{3} \mathrm{O}_{4}$ Graphene electrode in $6.0 \mathrm{M} \mathrm{KOH}$ solution are presented in the Nyquist (complex plane) representation in Fig. 6. Before recording each spectrum, the electrode was first kept at the applied potential to equilibrate for $300 \mathrm{~s}$. The corresponding Naquist plot can be as Figure 5 and 6 and we can confirm that the impedance curve with respect to frequency is a hyperbola suggesting porous pore electrode due to adsorption of graphene molecules on $\mathrm{Fe}_{3} \mathrm{O}_{4}$ electrodes [15].

Scanning electron microscopy (SEM) was performed to investigate structure, morphology and size of electrode material before discharge-charge cycles measurement. Figure 7 shows $\mathrm{SEM}$ images of $\mathrm{Fe} / \mathrm{Fe}_{3} \mathrm{O}_{4} /$ Graphene electrode material synthesized by above procedure taken from JEOL JSM 5600LV make SEM instrument. XRD and SEM results shows that the $\mathrm{Fe}_{3} \mathrm{O}_{4}$ that is produced through oxidation of iron oxalate is reduced to $\mathrm{Fe}$ through $\mathrm{Fe}(\mathrm{OH})_{2}[16]$. 


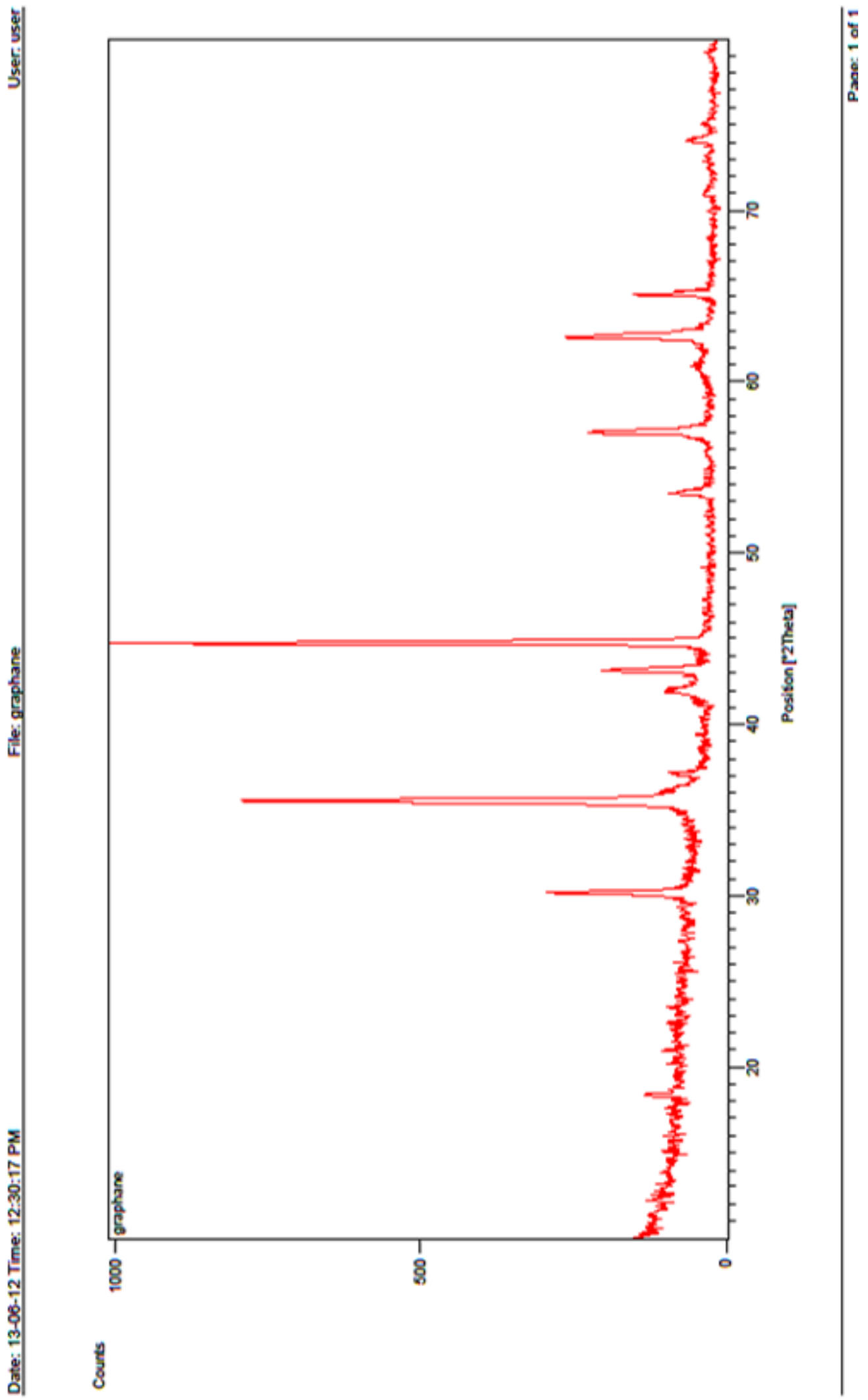

Figure 2. XRD pattern of $\mathrm{Fe} / \mathrm{Fe}_{3} \mathrm{O}_{4} / \mathrm{Graphene}(45 \mathrm{mg})$ negative electrode material. 


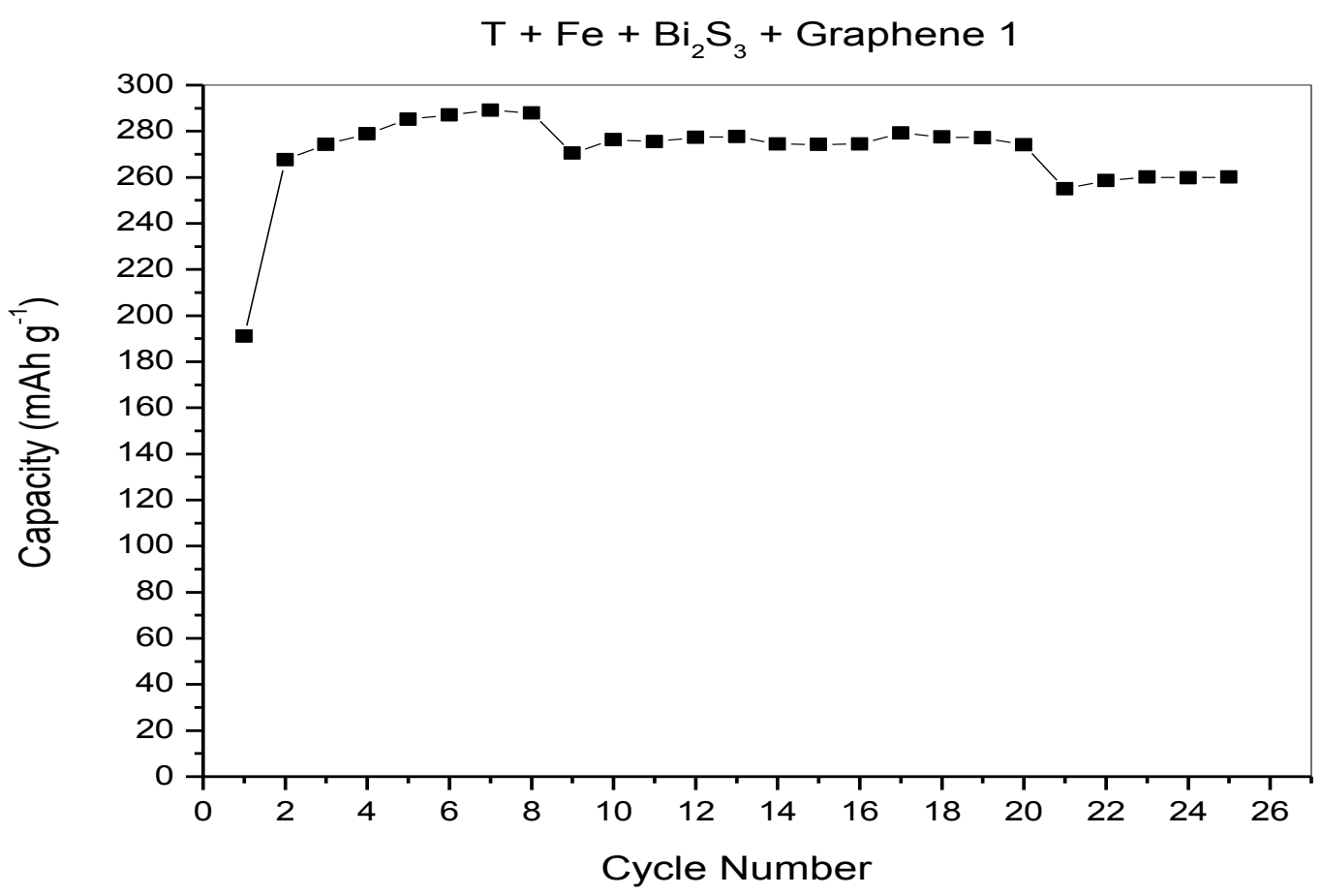

Figure 3. Capacity values of $\mathrm{Fe} / \mathrm{Fe}_{3} \mathrm{O}_{4} / \mathrm{Graphene}(30 \mathrm{mg})$ negative electrode as a function of charge/discharge cycle.

$\mathrm{T}+\mathrm{Fe}+\mathrm{Bi}_{2} \mathrm{~S}_{3}+$ Graphene 2

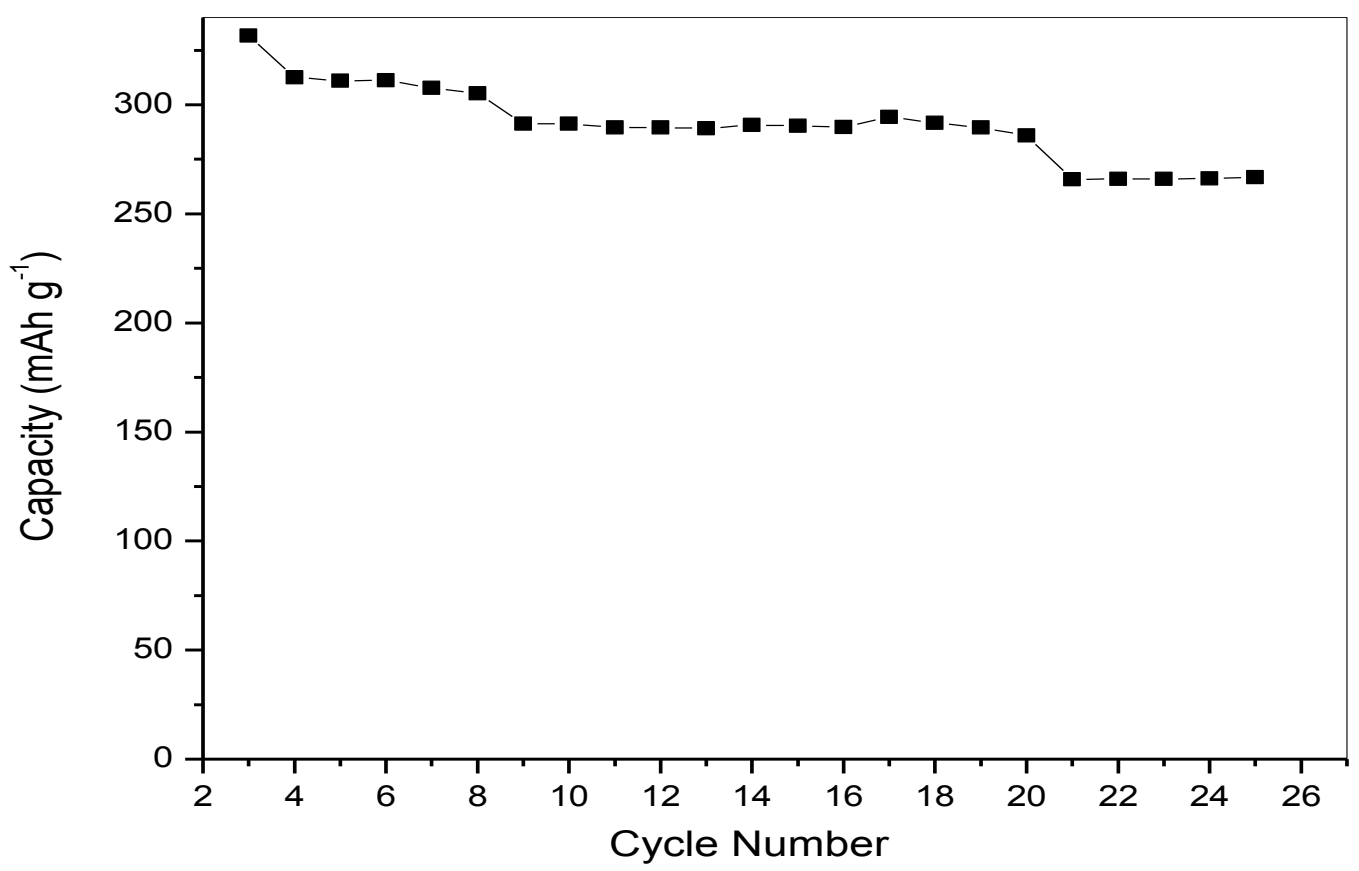

Figure 4. Capacity values of $\mathrm{Fe} / \mathrm{Fe}_{3} \mathrm{O}_{4} / \mathrm{Graphene}(45 \mathrm{mg})$ negative electrode as a function of charge/discharge cycle. 


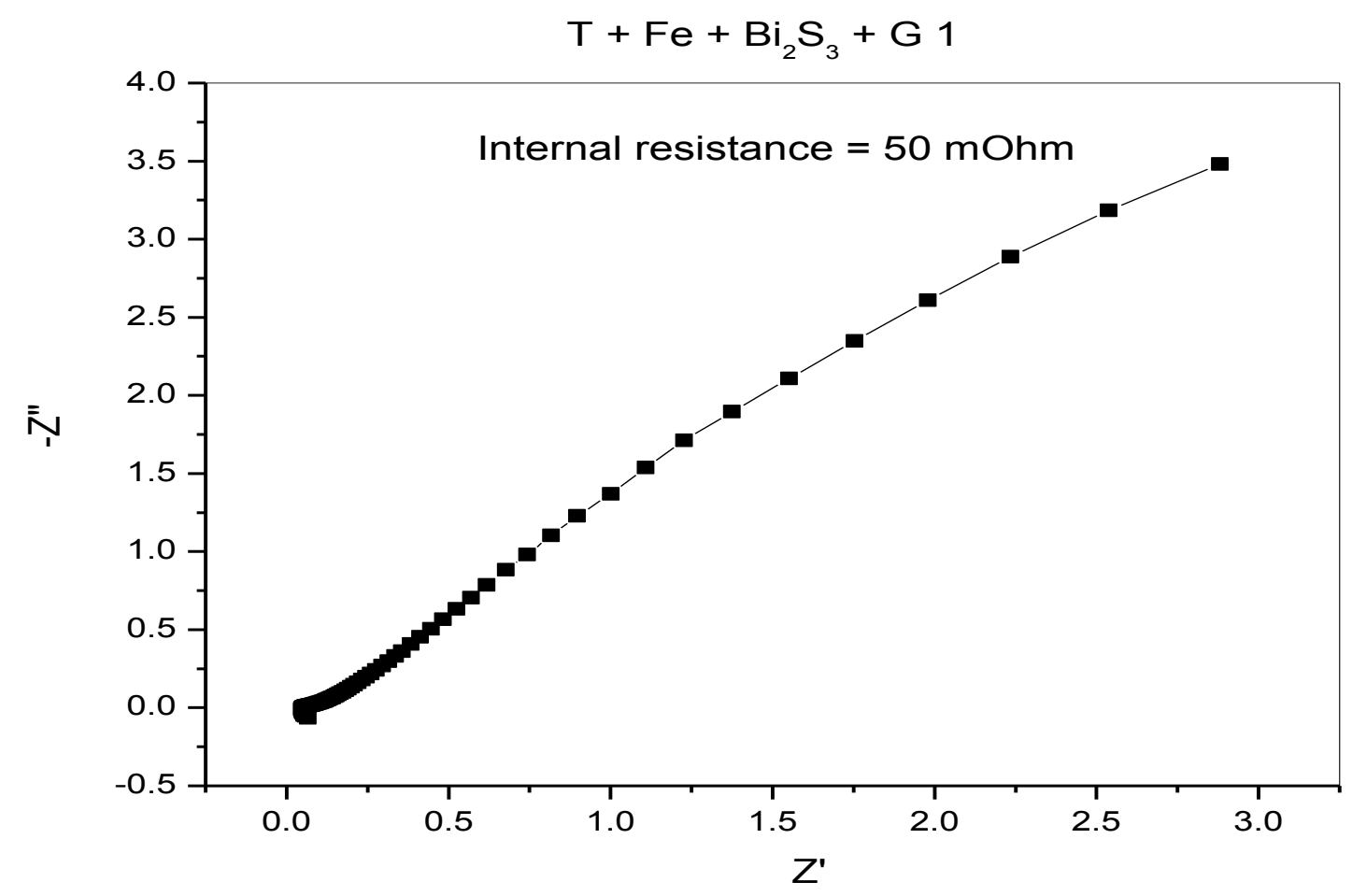

Figure 5. Impedance study of $\mathrm{Fe} / \mathrm{Fe}_{3} \mathrm{O}_{4} /$ Graphene electrode (Nyquist Plot).

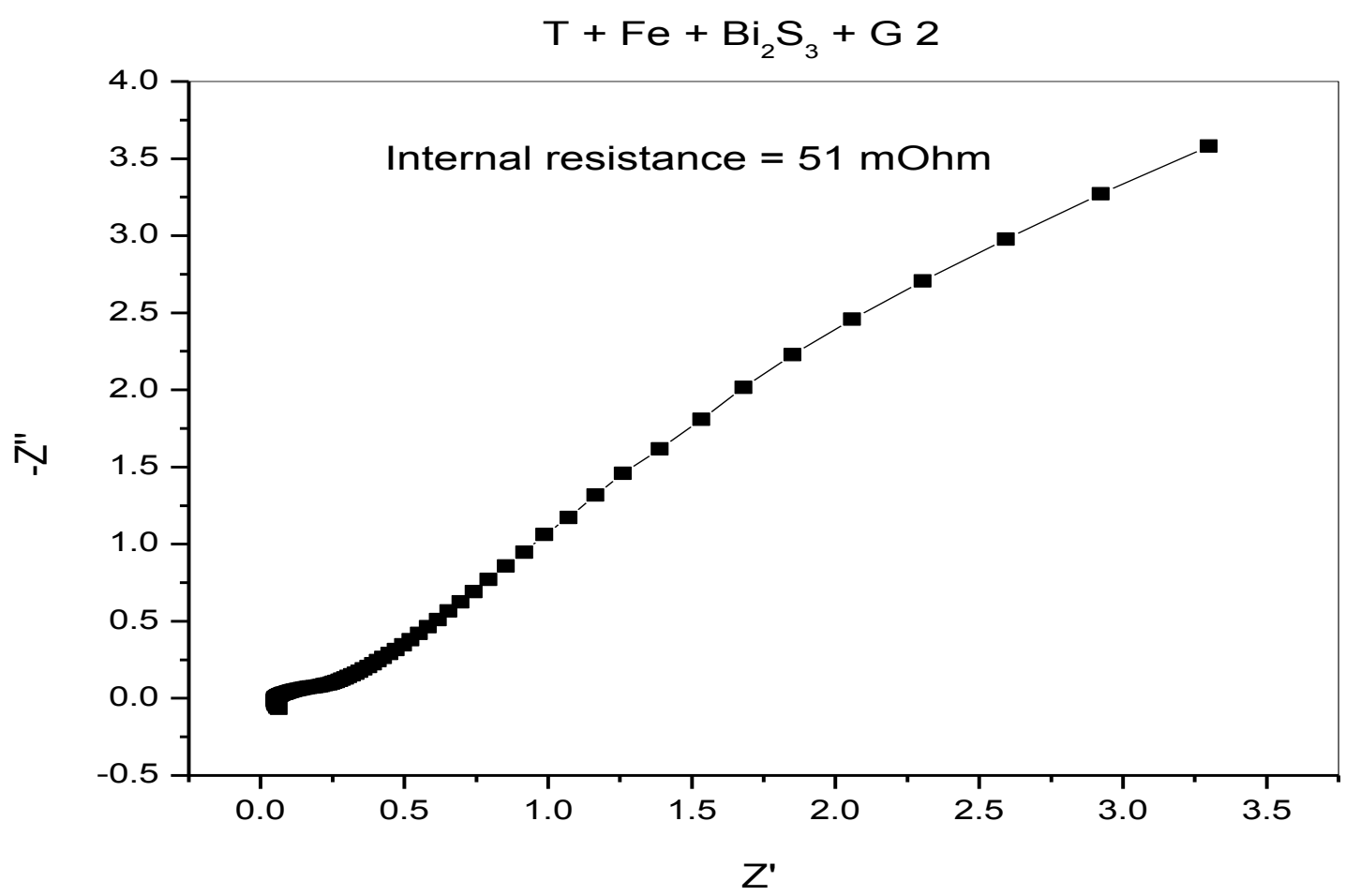

Figure 6. Impedance study of $\mathrm{Fe} / \mathrm{Fe}_{3} \mathrm{O}_{4} /$ Graphene electrode (Nyquist Plot). 


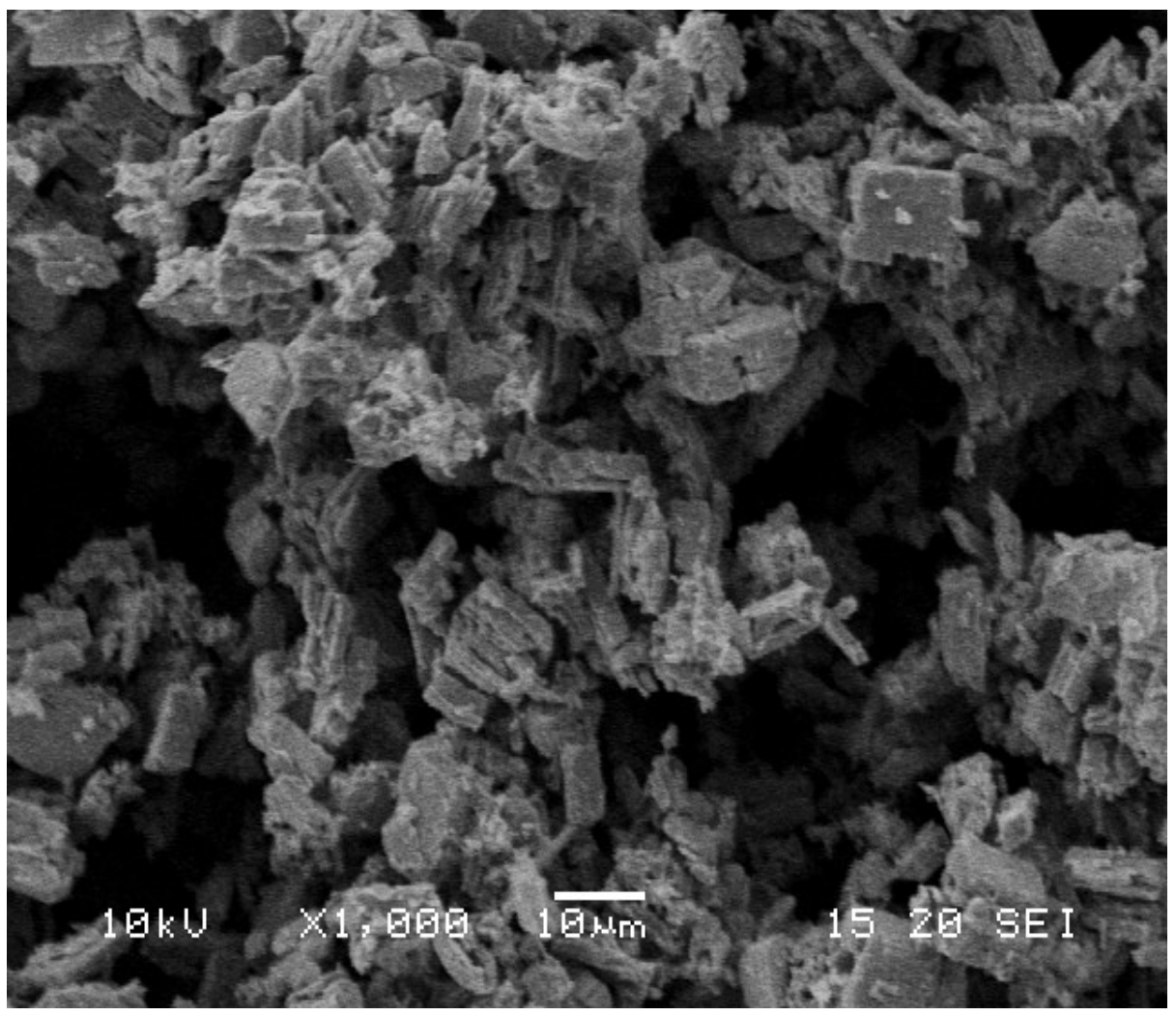

a) SEM image at $X 1,000$ magnification.

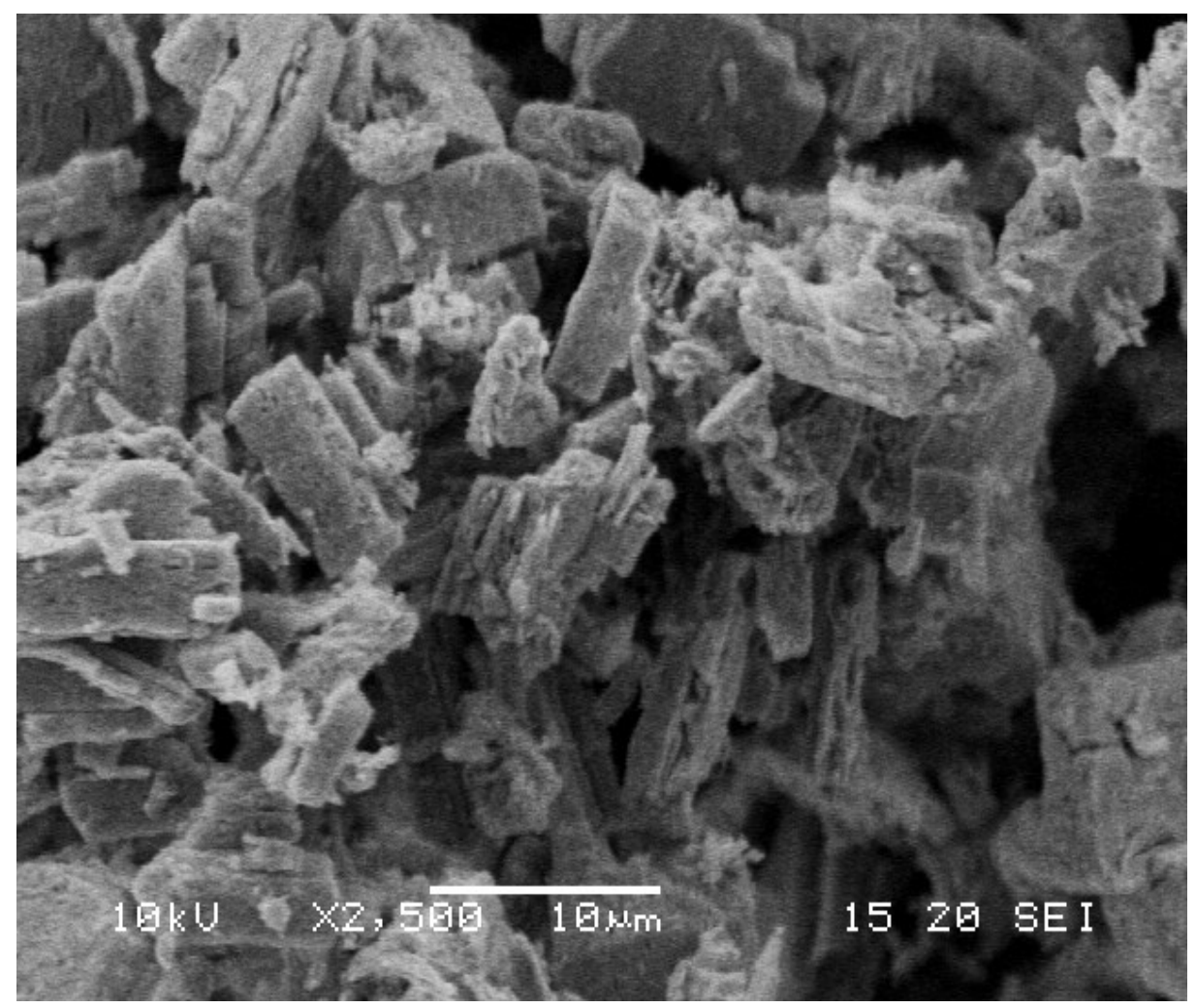

b) SEM image at X2, 500 magnification. 


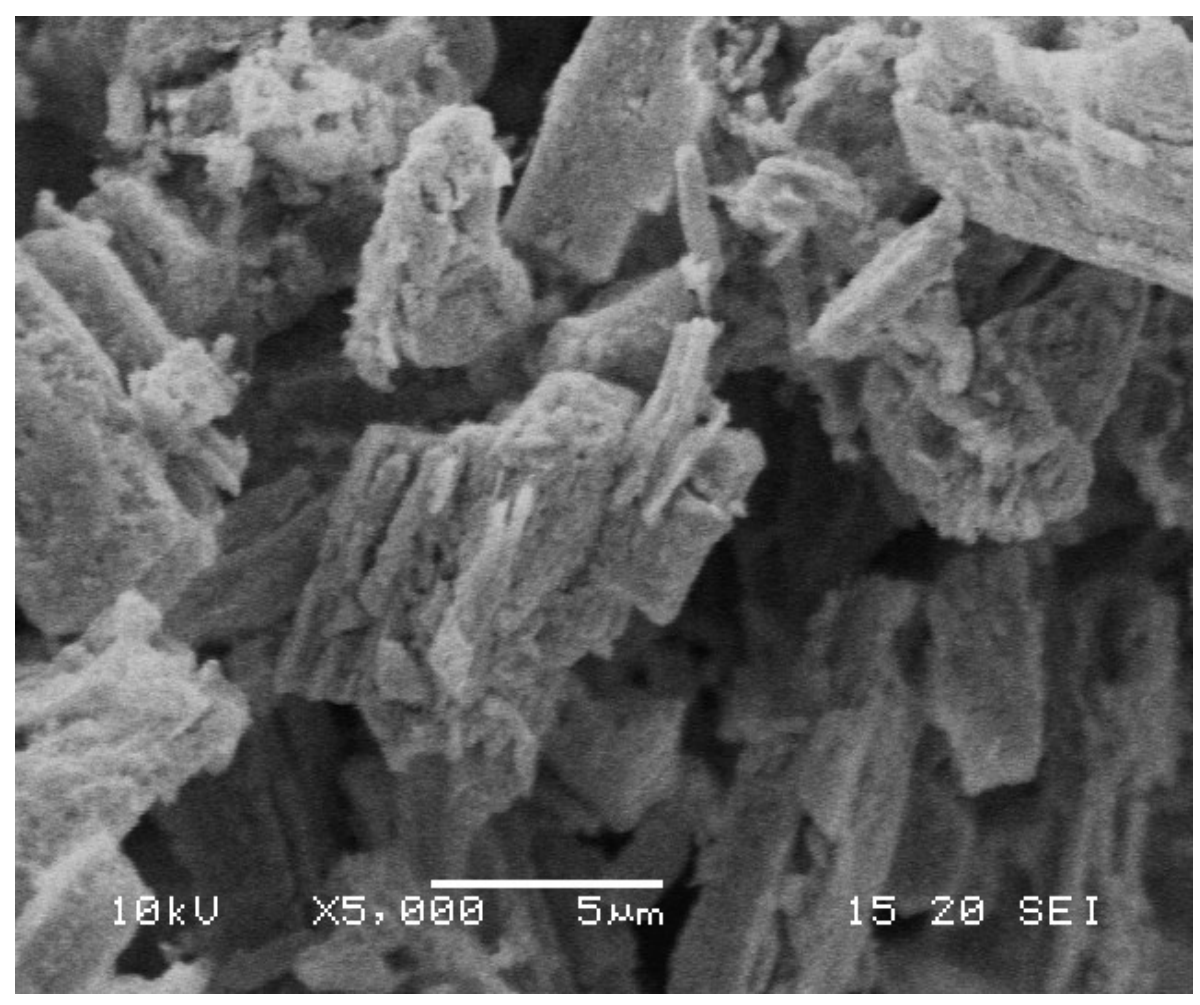

c) SEM image at X5,000 magnification.

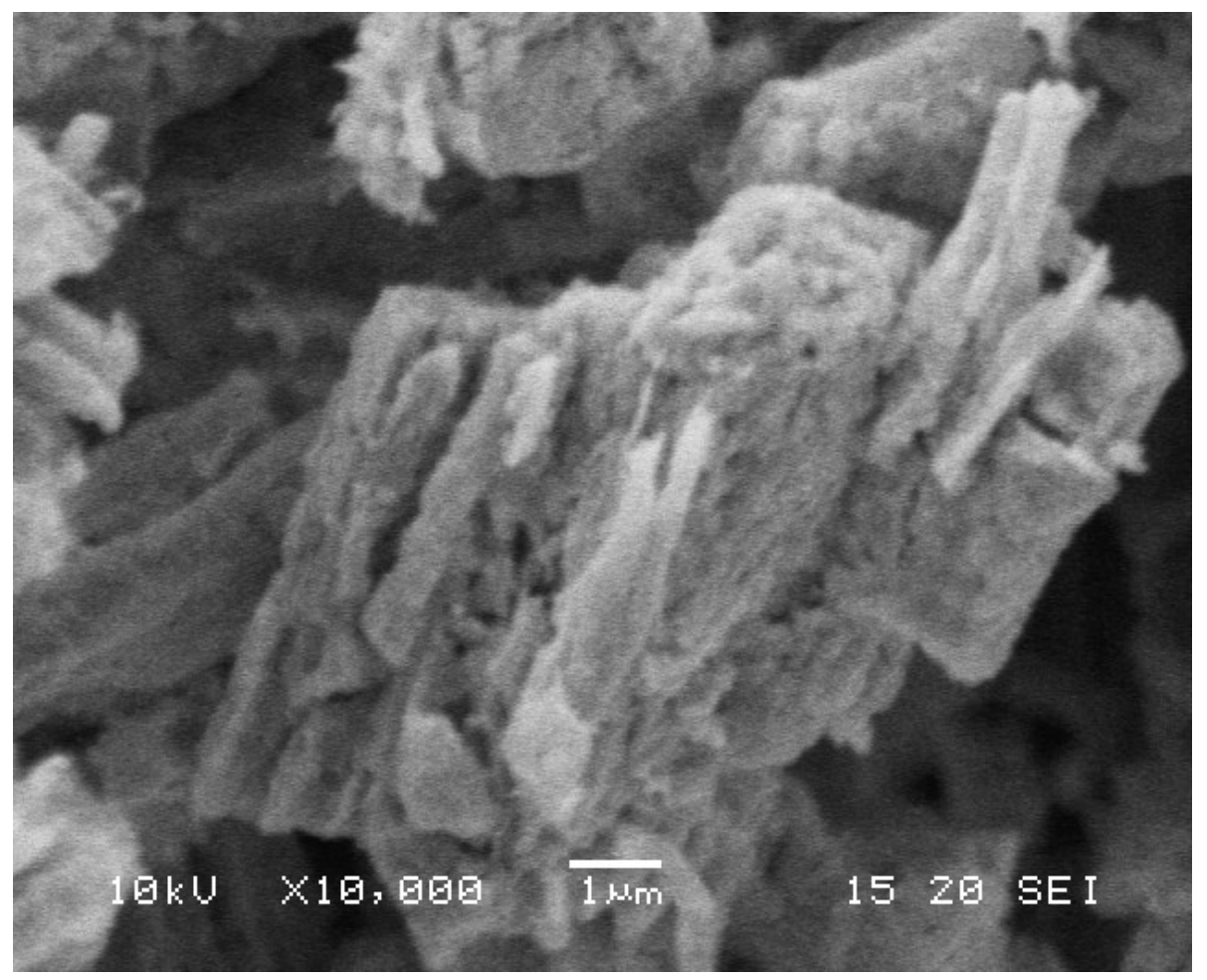

d) SEM image at X10,000 magnification.

Figure 7. SEM images of $\mathrm{Fe} / \mathrm{Fe}_{3} \mathrm{O}_{4} /$ Graphene negative electrode material. 
Therefore, it is likely that the uniform dispersion of Fe particles is attributable to the dissolution-deposition process between $\mathrm{Fe}$ and $\mathrm{Fe}(\mathrm{OH})_{2}$ via $\mathrm{HFeO}_{2}^{-}$[17].

SEM micrographs of the magnetite powders demonstrate that the morphology of the oxalate crystals is preserved during the course of thermal decomposition and has a strong impact on the shape and agglomeration behavior of the magnetite particles. The $\beta$-oxalate crystals have transformed into magnetite at 400 and $600{ }^{\circ} \mathrm{C}$ under grain growth conditions of 45 minutes. The obtained magnetite consists of bulky agglomerates of 2-3 $\mu \mathrm{m}$ size (Fig. 7c) that do hardly form bigger agglomerates. Magnetite prepared at $600{ }^{\circ} \mathrm{C}$ still consists of loose agglomerates. In contrast, thermal decomposition transforms the larger prism-shaped $\alpha$ ferrous-oxalate crystals into completely different magnetite morphology.

\section{CONCLUSIONS}

$\mathrm{Fe} / \mathrm{Fe}_{3} \mathrm{O}_{4} / \mathrm{Graphene}$ composite electrode material was synthesized by a thermal reduction method and then used as anode material for a rechargeable $\mathrm{Ni} / \mathrm{Fe}$ alkaline batteries. Reduced graphene $/ \mathrm{Fe} / \mathrm{Fe}_{3} \mathrm{O}_{4}$ composite electrode material was prepared using a facile three step synthesis involving synthesis of iron oxalate and subsequent reduction of exfoliated graphene oxide and iron oxalate by thermal decomposition method. The synthesis approach presents a promising route for a large-scale production of reduced graphene $/ \mathrm{Fe} / \mathrm{Fe}_{3} \mathrm{O}_{4}$ composite as electrode material for $\mathrm{Ni} / \mathrm{Fe}$ rechargeable batteries. The particle size and structure of the samples were characterized by SEM and XRD. Their electrochemical performance was also studied. Internal resistance found from impedance study was 50 and 51 mohm for $\mathrm{Fe} / \mathrm{Fe}_{3} \mathrm{O}_{4} /$ Graphene 1 and 2 electrodes, respectively. As an anode material for $\mathrm{Ni} / \mathrm{Fe}$ batteries, reduced graphene $/ \mathrm{Fe} / \mathrm{Fe}_{3} \mathrm{O}_{4}$ composite exhibited discharge and charge capacities of $280 \mathrm{mAh} / \mathrm{g}$, based on total mass of composite, with good cycling performance and rate capability. The result shows that the $\mathrm{Fe} / \mathrm{Fe}_{3} \mathrm{O}_{4} / \mathrm{Graphene}$ composite electrode material prepared by this method is nanosized.

\section{References}

[1] A. K. Shukla, S. Venugopalan, B. Hariprakash, J. Power Sources 100 (2001) 125.

[2] P. Periasamy, B. R. Babu, S. V. Iyer, J. Power Sources 62 (1996) 9.

[3] C. A. C. Souza, I.A. Carlos, M. Lopes, G.A. Finazzi, M. R. H. de Almeida, J. Power Sources 132 (2004) 288.

[4] D. Yamashita, Y. Yamamoto, K. Masuse, H. Yoshida, Nippon Kagaku Kaishi (1978) 525 .

[5] C. Chakkaravarthy, P. Periasamy, S. Jegannathan, K. I. Vasu, J. Power Sources 35 (1991) 21.

[6] A. K. Shukla, M. K. Ravikumar, T. S. Balasubramanian, J. Power Sources 51 (1994) 29.

[7] M. K. Ravikumar, T. S. Balasubramanian, A. K. Shukla, J. Power Sources 56 (1995) 209.

[8] W. C. He, H. B. Shao, Q. Q. Chen, J. M. Wang, J. Q. Mang, Acta Phys. Chim. Sin. 23 (2007) 1525. 
[9] K. C. Huang, K. S. Chou, Electrochem. Commun. 9 (2007) 1907.

[10] B. T. Hang, M. Eashira, I. Watanabe, S. Okada, J. I. Yamaki, S. H. Yoon, I. Mochida, J. Power Sources 143 (2005) 256.

[11] B. T. Hang, H. Hayashi, S. H. Yoon, S. Okada, J. Yamaki, J. Power Sources 178 (2008) 393.

[12] B. T. Hang, T. Watanabe, M. Eashira, S. Okada, J. Yamaki, S. Hata, S. H. Yoon, I. Mochida, J. Power Sources 150 (2005) 261.

[13] B. T. Hang, T. Watanabe, M. Eashira, I. Watanabe, S. Okada, J. Yamaki, Electrochem. Solid State Lett. 8 (2005) A 476.

[14] K. Ujimine, A. Tsutsumi, J. Power Sources 160 (2006) 1431.

[15] Chen-Yu Kao, Kan-Sen Chou, J. Power Sources 195 (2010) 2399-2404.

[16] Kuo-Cheng Huang, Kan-Sen Chou, Electrochemistry Communications 9 (2007) 19071912.

[17] A. K. Shukla, S. Venugopalan, B. Hariprakash, J. Power Sources 100 (2001) 125-148.

[18] W. Sienicki, M. Wojtewicz, International Letters of Chemistry, Physics and Astronomy 4 (2012) 76-81. 